\section{Pacific Northwest}

National Laboratory

Operated by Battelle for the

U.S. Department of Energy

\title{
Analysis of Percent On-Cell Reformation of Methane in SOFC Stacks: Thermal, Electrical, and Stress Analysis
}

\author{
K. P. Recknagle \\ S. T. Yokuda \\ D. T. Jarboe \\ M. A. Khaleel
}

April 2006

Prepared for the U.S. Department of Energy

under Contract DE-AC05-76RL01830 


\section{Analysis of Percent On-Cell Reformation of Methane in SOFC Stacks: Thermal, Electrical, and Stress Analysis}

K. P. Recknagle

S. T. Yokuda

D. T. Jarboe

M. A. Khaleel

April 2006

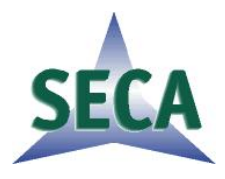

Prepared for the U.S. Department of Energy under Contract DE-AC05-76RL01830 


\title{
DISCLAIMER
}

This report was prepared as an account of work sponsored by an agency of the United States Government. Neither the United States Government nor any agency thereof, nor Battelle Memorial Institute, nor any of their employees, makes any warranty, express or implied, or assumes any legal liability or responsibility for the accuracy, completeness, or usefulness of any information, apparatus, product, or process disclosed, or represents that its use would not infringe privately owned rights. Reference herein to any specific commercial product, process, or service by trade name, trademark, manufacturer, or otherwise does not necessarily constitute or imply its endorsement, recommendation, or favoring by the United States Government or any agency thereof, or Battelle Memorial Institute. The views and opinions of authors expressed herein do not necessarily state or reflect those of the United States Government or any agency thereof.

\author{
PACIFIC NORTHWEST NATIONAL LABORATORY \\ operated by \\ BATTELLE \\ for the \\ UNITED STATES DEPARTMENT OF ENERGY \\ under Contract DE-AC05-76RL01830 \\ Printed in the United States of America \\ Available to DOE and DOE contractors from the \\ Office of Scientific and Technical Information, \\ P.O. Box 62, Oak Ridge, TN 37831-0062; \\ ph: (865) 576-8401 \\ fax: (865) 576-5728 \\ email: reports@adonis.osti.gov
}

Available to the public from the National Technical Information Service, U.S. Department of Commerce, 5285 Port Royal Rd., Springfield, VA 22161

ph: (800) 553-6847

fax: (703) 605-6900

email: orders@ntis.fedworld.gov

online ordering: http://www.ntis.gov/ordering.htm 


\title{
Analysis of Percent On-Cell Reformation of Methane in SOFC Stacks: Thermal, Electrical, and Mechanical Performance
}

\author{
K. P. Recknagle \\ S. T. Yokuda \\ D. T. Jarboe \\ M. A. Khaleel
}

April 2006

Work Performed under

SECA Core Technology Program and

Contract DE-AC05-76RL01830

Report Submitted to:

Don Collins, Lane Wilson, Travis Shultz and Wayne Surdoval

National Energy Technology Laboratory, Pittsburgh, PA

Pacific Northwest National Laboratory

Richland, WA 99352 


\section{Executive Summary}

This report summarizes a parametric analysis performed to determine the effect of varying the percent on-cell reformation (OCR) of methane on the thermal, electrical, and mechanical performance for a generic, planar solid oxide fuel cell (SOFC) stack design. OCR of methane can be beneficial to an SOFC stack because the reaction (steam-methane reformation) is endothermic and can remove excess heat generated by the electrochemical reactions directly from the cell. The heat removed is proportional to the amount of methane reformed on the cell. Rapid reaction kinetics provided by the high-temperature SOFC operation and excess steam over the nickel-based anode catalyst ensure complete methane conversion. Thus, the thermal load varies with methane concentration entering the stack. The endotherm due to the fast reformation reaction can cause a temperature depression on the anode near the fuel inlet, resulting in large thermal stresses. This effect depends on factors that include inflowing methane concentration, local temperature, and stack geometry.

The analysis assumed the fuel would be partially to fully pre-reformed in an external reformer such that the desired fuel compositions would be delivered to the stack, where the remaining percentage of the reformation reaction would be completed on-cell. Simulations were performed using an SOFC stack modeling tool developed at PNNL and validated for the prediction of fuel use, on-cell methane reforming, and distribution of temperature. The study was performed using three-dimensional stack model geometries. Cross-flow, co-flow, and counter-flow configuration stacks of $10 \times 10-$ and $20 \times 20-\mathrm{cm}$ cell sizes were examined. Thermal performance was evaluated based on the predicted maximum temperature difference on the anode. Electrical performance was based on the predicted power output. Mechanical performance was based on the maximum principal stress on the anode. Fuel utilization was established at $75 \%$. The effect of cathode air cooling was included in the study by examination of $30 \%$ and $15 \%$ air utilizations.

The analysis showed for the counter-flow and cross-flow stacks of $10 \times 10-\mathrm{cm}$ size the stress and temperature difference would be minimized when between 40 and $50 \%$ of the reformation reaction occurred on the anode. Gross electrical power density was virtually unaffected by \%OCR. For all stack configurations and sizes the inflow temperature increased with \%OCR as the subsequent heat load decreased. Cooling provided by the cathode airflow associated with $30 \%$ air utilization was not substantially improved upon by $15 \%$ air use for the smaller $(10 x 10-\mathrm{cm})$ stack size. The increased airflow associated with $15 \%$ air utilization was needed for cooling the larger $(20 \times 20-\mathrm{cm})$ stacks. The co-flow stack exhibited the largest benefit from the additional cathode air cooling and had the lowest anode stresses of the 20x20-cm stacks. For the conditions and particular generic stacks of this study, the results suggest 40 to $50 \%$ OCR should be considered for cross-flow and counter-flow stacks, and higher percentages may be desirable in co-flow stacks. Results of this study also suggest that 30\% air utilization may be sufficient for 10x10-cm cell stacks, and 15\% air utilization should be considered for 20x20-cm cell stacks. 


\section{Acknowledgments}

Pacific Northwest National Laboratory is operated by Battelle for the U.S. Department of Energy under Contract DE-AC05-76RL01830. The work summarized in this paper was funded as part of the Solid-State Energy Conversion Alliance (SECA) Core Technology Program by the U.S. Department of Energy’s National Energy Technology Laboratory (NETL).

The authors would like to thank Dave King for providing materials testing and methane conversion data and Prabhakar Singh for helpful discussions regarding on-cell reformation. 


\section{Contents}

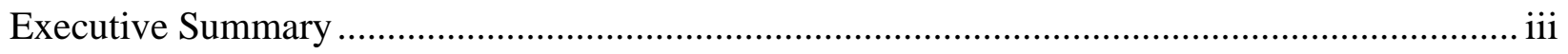

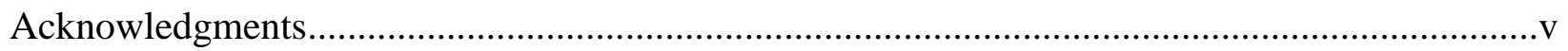

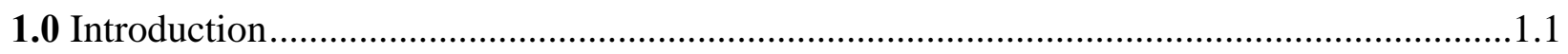

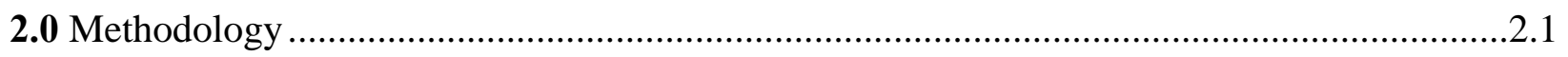

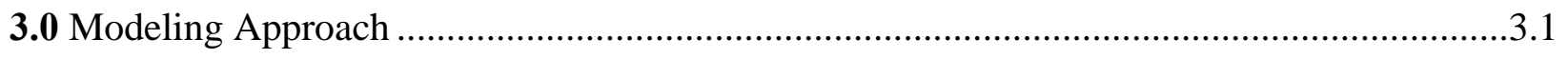

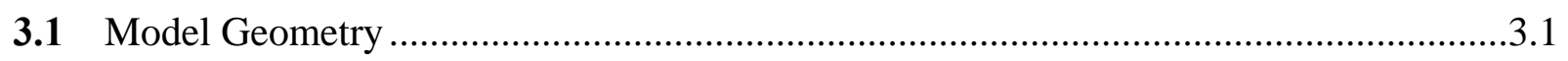

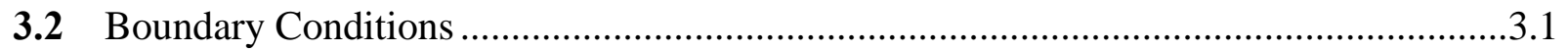

3.3 Electrochemical Performance and Material Properties .................................................2

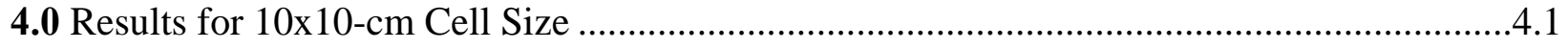

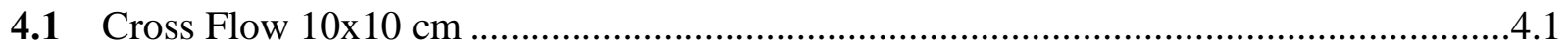

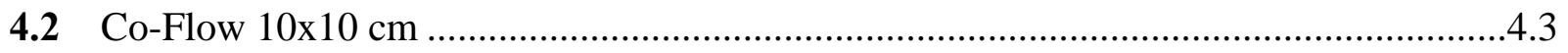

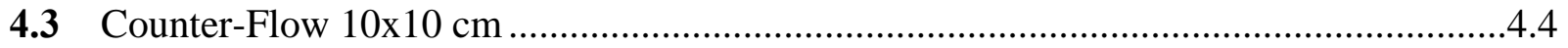

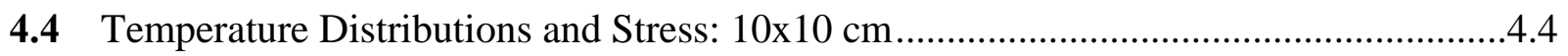

5.0 Results: 20x20-cm Cell Size ......................................................................................

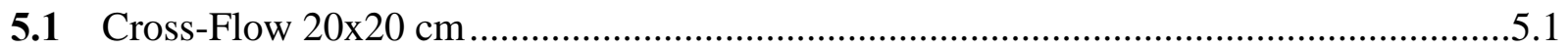

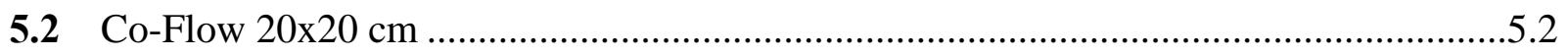

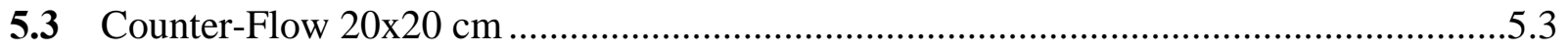

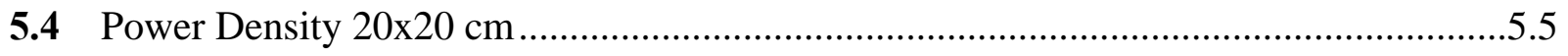

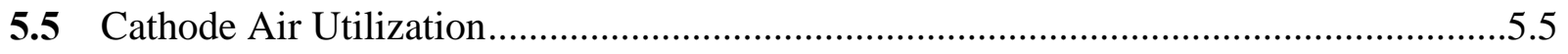

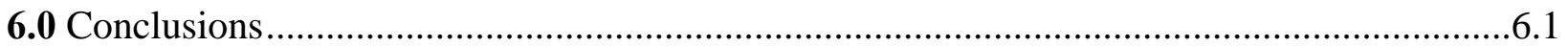

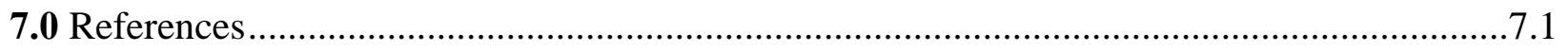

Appendix - Molar Compositions of Partially Reformed Fuel Mixtures ......................................1 


\section{Figures}

3.1 Exploded Assemblies for the Co-Flow, Cross-Flow, and Counter-Flow Configuration for the 10x10 and 20x20 Cases.

3.2 Temperature Dependent Elastic Modulus (Pascals)...................................................................

3.3 Temperature Dependent Coefficient of Thermal Expansion $(1 / \mathrm{T})$.................................3.1

4.1 Cell Temperature Difference and Inflow Fuel/Air Temperature Versus

Percent On-Cell Reforming for 10x10-cm Cross-Flow Cases........................................4.1

4.2 Cell Temperature Difference and Inflow Fuel/Air Temperature Versus

Percent On-Cell Reforming for 10x10 cm Co-Flow Cases.............................................4.3

4.3 Cell Temperature Difference and Inflow Fuel/Air Temperature Versus

Percent On-Cell Reforming for 10x10-cm Counter-Flow Cases .....

4.4 Distributions of Anode Temperature and Maximum Principal Stress

within a 10x10-cm Counter-Flow Stack

5.1 Cell Temperature Difference and Inflow Fuel/Air Temperature Versus

Percent On-Cell Reforming for 20x20-cm Cross-Flow Cases.

5.2 Cell Temperature Difference and Inflow Fuel/Air Temperature Versus

Percent On-Cell Reforming for 20x20-cm Co-Flow Cases

5.3 Cell Temperature Difference and Inflow Fuel/Air Temperature Versus

Percent On-Cell Reforming for 20x20-cm Counter-Flow Cases.

5.4 Distributions of Anode Temperature and Maximum Principal Stress within a 10x10-cm Counter-Flow Stack

\section{Tables}

2.1 Mass Compositions of Partially Reformed Fuel Mixtures Supplied from an

External Reformer to the Stack

3.1 Material Properties Used in the Simulations ............................................................. 3.2

4.1 Summary of Thermal Load Results for 10x10-cm Cell Size ........................................ 4.2

4.2 Thermal Stress Results for 10x10-cm Cell Size.......................................................... 4.2

5.1 Summary of Thermal Load Results for 20x20-cm Cell Size ......................................... 5.2

5.2 Thermal Stress Results for 20x20-cm Cell Size....................................................... 5.2 


\subsection{Introduction}

The solid oxide fuel cell (SOFC) industry continues to develop larger, more powerful cell stacks for stationary power applications, and thermal management remains a critical issue for the reliable operation of these stacks. On-cell reformation (OCR) of methane is an effective means of removing excess heat generated within an SOFC stack. OCR refers to reforming the fuel directly on the anode. Of the various heat removal methods available for use in SOFC stacks, OCR has the potential to be the most beneficial to the overall system. The reformation reaction is endothermic and, when used on the anode, immediately removes excess heat generated by the electrochemical oxidation reactions. The demand on an external fuel reformer (and associated heat exchanger) decreases as the percentage of the reformation reaction that takes place on-cell increases. Thus, the size of the external reformer and related heat exchanger could be decreased while also decreasing the thermal load experienced by the stack.

In the reformation reaction, methane combined with steam is converted at high temperature to hydrogen and carbon monoxide in the presence of a nickel catalyst such as the typical nickelbased (Ni-YSZ) SOFC anode (Eq. 1). The hydrogen and carbon dioxide gas products can be consumed electrochemically in the oxidation reactions (Eq. 2 and 3) and are also subject to the rapid water-gas shift reaction (Eq. 4).

$$
\begin{gathered}
\mathrm{CH}_{4}+\mathrm{H}_{2} \mathrm{O} \Rightarrow 3 \mathrm{H}_{2}+\mathrm{CO} \\
\mathrm{H}_{2}+1 / 2 \mathrm{O}_{2} \rightarrow \mathrm{H}_{2} \mathrm{O}+2 e^{-} \\
\mathrm{CO}+1 / 2 \mathrm{O}_{2} \rightarrow \mathrm{CO}_{2}+2 e^{-} \\
\mathrm{CO}+\mathrm{H}_{2} \mathrm{O} \leftrightarrow \mathrm{CO}_{2}+\mathrm{H}_{2}
\end{gathered}
$$

On-cell reformation is attractive because of the decreased thermal load it can provide as well as the cost benefits of decreased reformer size. However, the kinetics of the reformation reaction on a standard Ni-YSZ anode is rapid, and with increasing \%OCR, the resultant endotherm can cause a significant local temperature depression near the fuel inlet on the anode. Cooling near the fuel inlet and subsequently increased heating downstream due to increased hydrogen concentration and electrical current density can set up a large difference between the minimum and maximum temperatures on the cell $(\Delta \mathrm{T})$. Along with the cell $\Delta \mathrm{T}$ there can be and increase in the thermal stresses on the anode ${ }^{1}$ creating an unreliable condition for cell operation.

The objective of this report is to analyze the effect of varying the percentage of the reformation reaction occurring on-cell on the stack performance. In particular, this work addresses the effect that variable \%OCR has on the thermal, electrical, and mechanical performance of a generic stack design with co-flow, counter-flow, and cross-flow configurations 
and 10x10- and 20x20-cm active cell sizes. The thermal performance is evaluated based on the predicted cell $\Delta \mathrm{T}$ with analysis of the heat load and balances. The electrical performance is based on the predicted output power density. The mechanical performance is based on the maximum principal anode stress. 


\subsection{Methodology}

A computational modeling tool for simulating the multi-physics of SOFC operation was used in this study. The PNNL developed SOFC-MP code solves the equations for mass transport, energy, and electrochemistry required to predict the fluid flow, temperature, species, and current density distributions in a three-dimensional SOFC geometry. ${ }^{2,3,4}$ The electrochemistry model used was described by Chick et al., ${ }^{5}$ calibrated $^{6,7}$ for application to planar stack simulations, and updated to provide an improved anode concentration polarization model. ${ }^{8}$ The capabilities of these tools have also been expanded to incorporate steam-methane reformation for simulating on-cell reforming ${ }^{9}$ and have been updated with a rate expression derived experimentally at PNNL: ${ }^{10}$

$$
\left(-r_{\mathrm{CH}_{4}}\right)\left(\mathrm{mol} / \mathrm{gm}_{\mathrm{cat}} / \mathrm{s}\right)=(2.188 \mathrm{E} 8) e^{-\frac{E_{a c t}}{R T}} C_{\mathrm{CH}_{4}} C_{\mathrm{CO}_{2}}^{-0.0134}
$$

The temperature, $T$, is in Kelvin, the universal gas constant, $R$ is $8.314 \mathrm{~J} / \mathrm{mol}-\mathrm{K}$, the activation energy, $E_{a c t}$, is $94,950 \mathrm{~J} / \mathrm{mol}$, and the concentrations, $C_{\mathrm{i}}$, are in units of mol/cc. A steam-to-carbon ratio of at least $1.0(\mathrm{~S}: \mathrm{C}=1.0)$ was used in all of King's tests. While the methane conversion rate showed no dependence on the steam concentration, a slight hindering effect was identified due to the concentration of $\mathrm{CO}_{2}$. This expression (Eq. 5) represents fast kinetics although it does include a self-leveling effect. As the temperature decreases locally due to the endotherm, the reaction slows as a consequence. The rate increases with increased methane concentration. Hence, larger endothermic effects are expected with increased OCR.

In the study it was assumed the unreformed fuel mixture containing methane, steam, and nitrogen passed through a fuel stream pre-heater to an external reformer using excess steam ( $\mathrm{S}: \mathrm{C}=2.0)$ ultimately to prevent coking of the anode. In Eq. (1) through (4), one mole of $\mathrm{CH}_{4}$ is converted to three moles of $\mathrm{H}_{2}$ and one mole of CO. In the shift reaction, one mole of $\mathrm{CO}$ (and $\mathrm{H}_{2} \mathrm{O}$ ) is converted to one mole of $\mathrm{H}_{2}$ (and $\mathrm{CO}_{2}$ ); or the $\mathrm{CO}$ can be oxidized directly, as $\mathrm{H}_{2}$ is for generating electrical current. Thus the fuel content of gas mixtures that contain $\mathrm{CO}$ and $\mathrm{CH}_{4}$ (on a mol/s basis) is the sum of mol/s $\mathrm{H}_{2}, \mathrm{~mol} / \mathrm{s} \mathrm{CO}$ and four times the $\mathrm{mol} / \mathrm{s} \mathrm{CH}_{4}$.

This study examined fuels with compositions representing 0 to $80 \%$ OCR. Regardless of the fuel feed composition, the fuel content in all cases was $4.15 \mathrm{E}-06 \mathrm{~mol} / \mathrm{s} / \mathrm{cm}^{2}$. Table 2.1 summarizes the molar compositions of partially reformed fuel mixtures supplied from an external reformer to the stack for the simulations (see the appendix for mass compositions of the fuel mixtures). Methane made up 28\% of the total unreformed fuel mixture. When the fuel was $20 \%$ pre-reformed (in preparation for $80 \%$ OCR) the resulting mixture, as shown in Table 2.1, contained $20.2 \%$ methane, $11.8 \%$ hydrogen, $48.8 \%$ steam, etc. As the OCR decreased to zero, the methane was fully converted and the hydrogen and steam concentrations were $53.8 \%$ and $18.1 \%$, respectively. 
Table 2.1. Molar Compositions of Partially Reformed Fuel Mixtures Supplied from an External Reformer to the Stack (mole fraction)

\begin{tabular}{|l|l|l|l|l|l|l|}
\hline \multicolumn{1}{|c|}{$\mathbf{H}^{\mathbf{2}}$} & \multicolumn{1}{c|}{$\mathbf{C O}$} & \multicolumn{1}{c|}{$\mathbf{H}^{\mathbf{2}} \mathbf{O}$} & \multicolumn{1}{c|}{$\mathbf{C O}^{\mathbf{2}}$} & \multicolumn{1}{c|}{$\mathbf{C H}^{\mathbf{4}}$} & \multicolumn{1}{c|}{$\mathbf{N}^{\mathbf{2}}$} \\
\hline 0 & 0.538 & 0.127 & 0.181 & 0.052 & 0.000 & 0.101 \\
\hline 10 & 0.503 & 0.112 & 0.205 & 0.056 & 0.019 & 0.105 \\
\hline 20 & 0.465 & 0.096 & 0.232 & 0.059 & 0.039 & 0.109 \\
\hline 30 & 0.423 & 0.080 & 0.262 & 0.061 & 0.060 & 0.114 \\
\hline 40 & 0.376 & 0.064 & 0.295 & 0.062 & 0.084 & 0.118 \\
\hline 50 & 0.324 & 0.049 & 0.333 & 0.061 & 0.110 & 0.124 \\
\hline 60 & 0.264 & 0.033 & 0.377 & 0.058 & 0.137 & 0.129 \\
\hline 70 & 0.196 & 0.020 & 0.428 & 0.052 & 0.168 & 0.136 \\
\hline 80 & 0.118 & 0.008 & 0.488 & 0.042 & 0.202 & 0.142 \\
\hline
\end{tabular}

After the electrochemical solution was obtained, the temperature profile was used as a load in a structural analysis to evaluate the stresses in the cell. The maximum principal stress of the anode was then evaluated for each of the cases. 


\subsection{Modeling Approach}

\subsection{Model Geometry}

Multiple model geometries were used in this work. Generic cross-flow, co-flow, and counter-flow planar SOFC three-dimensional stack models were created in 10x10- and 20x20-cm cell sizes. The footprints for the geometries are shown in Figure 3.1. Each model comprised 53,312 computational elements within the footprint of the three-dimensional stack. The models included 1-mm-tall fuel and air flow regions, 0.66-mm-thick PEN, 2-mm- ( 80 mil-) thick separator/interconnect plates top and bottom, and 0.2-mm-thick by 6-mm-wide glassceramic seals at the stack perimeter. The computational grid used within the active area consisted of 50 elements in both the $\mathrm{X}$ and $\mathrm{Y}$ planar coordinates.

a)

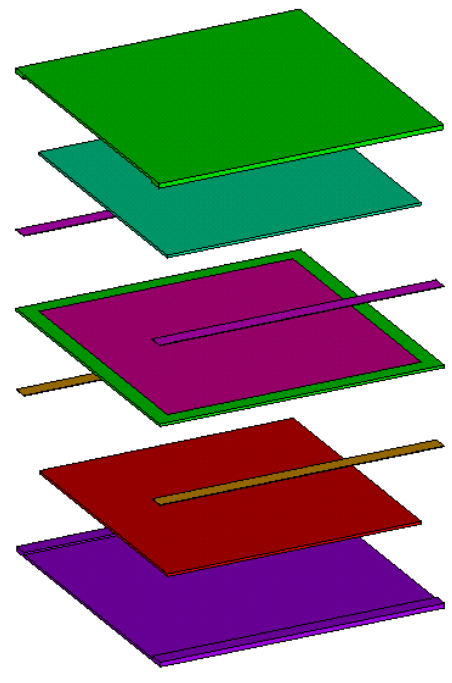

b)

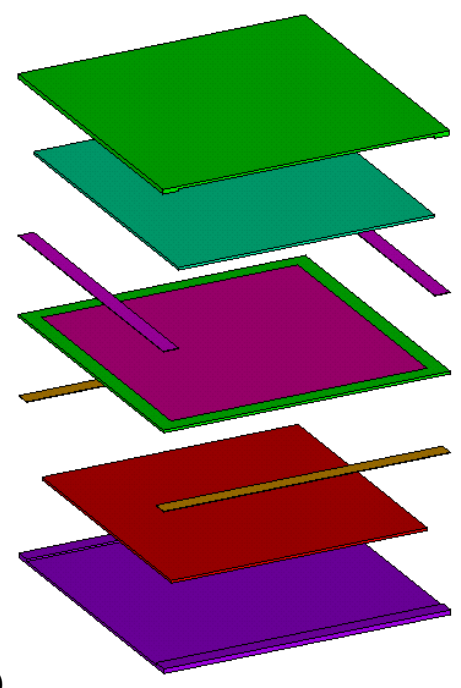

Figure 3.1. Exploded Assemblies for the a) Co- and Counter-Flow Configuration for the 10x10- and 20x20-cm Cases and b) Cross-Flow Configuration for the 10x10and 20x20-cm Cases. Geometries consist of (bottom to top) lower separator plate, cathode flow region/interconnect, lower seal, cell, upper seal, anode flow region/interconnect, and upper separator plate.

\subsection{Boundary Conditions}

Each model was constructed to represent a single repeating cell unit located at the mid-level of a large, multiple-cell stack, and gradients in the vertical direction were assumed small; thus cyclic boundaries were used at the top and bottom surfaces of the model to represent this condition. It was assumed the stack was operating within an insulated enclosure with an air gap between the stack and enclosure walls. Wall boundaries at the stack perimeter accounted for 
natural convection of air surrounding the stack and radiation across the gap to the container walls. Constant mass inflow boundaries were used for the air and fuel streams.

The solutions were adjusted to achieve average cell temperature and current density to $750^{\circ} \mathrm{C}$ and $0.6 \mathrm{~A} / \mathrm{cm}$, respectively. In the simulations, the iterative solutions for all cases were well converged with respect to mass, momentum, energy, chemistry, and electrochemistry. Because all cases simulated stack operation at the same average temperature and current density except for variations in the output power, the differences in net heat load were attributable to the heat removed by OCR. Subsequently, the thermal performance of each stack could be compared directly.

For the structural evaluation, minimal displacement support boundary conditions were used at the bottom of the cell. These simplified boundary conditions do not constrain the unit cell model as well as if it was within a full stack and thus enable more component deflection, which can contribute to the stress.

\subsection{Electrochemical Performance and Material Properties}

For these analyses, the electrochemical performance of a cell operating on the fully prereformed fuel was taken to be $0.60 \mathrm{~A} / \mathrm{cm}^{2}$ at $0.68 \mathrm{~V}$ and $75 \%$ fuel utilization, at an average cell temperature of $750^{\circ} \mathrm{C}$. Two air flow rates were used to examine the cooling effect of air at $30 \%$ and $15 \%$ air utilization. In the electrochemistry model, the Butler-Volmer parameters were set as $\alpha_{\mathrm{BV}}=0.6, \mathrm{k}_{\mathrm{BV}}=150,000 \mathrm{~A} / \mathrm{cm}^{2}$ and $\mathrm{E}_{\mathrm{act}, \mathrm{BV}}=118,000 \mathrm{~J} / \mathrm{mole}$. Anode, electrolyte, and cathode thicknesses were 600,10, and 50 microns, respectively. The anode and cathode porosity was $30 \%$, and the tortuosity was 2.5 for both electrodes. Thermal properties used in the model are summarized in Table 3.1. The temperature dependent elastic modulus (Pascals) and coefficients of thermal expansion (1/T) for the stack materials are shown in Figures 3.2 and 3.3, respectively.

Table 3.1. Thermal Properties Used in the Simulations

\begin{tabular}{|l|c|c|c|}
\hline \multicolumn{1}{|c|}{ Material } & $\begin{array}{c}\text { Density } \\
\left(\mathrm{kg} / \mathrm{m}^{3}\right)\end{array}$ & $\begin{array}{c}\text { Thermal Conductivity } \\
(\mathrm{W} / \mathrm{m}-\mathrm{K})\end{array}$ & $\begin{array}{c}\text { Specific Heat } \\
(\mathrm{J} / \mathrm{kg}-\mathrm{K})\end{array}$ \\
\hline Gases (air, fuel) & Ideal gas: $\rho=\rho(\mathrm{T})$ & $\begin{array}{c}\text { Multicomponent mass } \\
\text { weighted }\end{array}$ & $\begin{array}{c}\text { Multicomponent mass } \\
\text { weighted }\end{array}$ \\
\hline PEN & 4300 & 3 & 0.06 (steady) \\
\hline $\begin{array}{l}430 \text {-SS picture frame, } \\
\text { separator plate, spacers }\end{array}$ & 7700 & 13 & 0.08 \\
\hline Seal (glass) & 2800 & 1.05 & 0.06 \\
\hline Cathode flow space (effective) & Same as cathode air & $\begin{array}{c}13(\sim \text { half that of I/C } \\
\text { uniform channel/rib pitch) }\end{array}$ & Same as cathode air \\
\hline Anode flow space (effective) & Same as anode fuel & 9.1 & Same as anode fuel \\
\hline
\end{tabular}




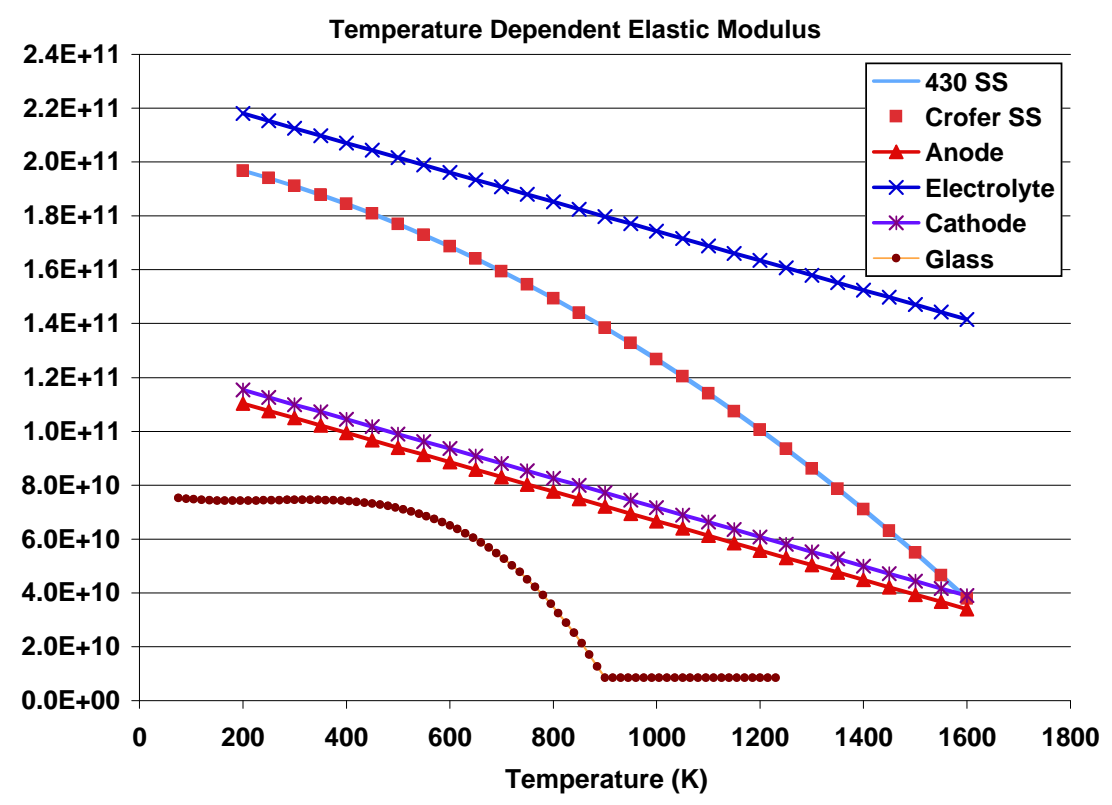

Figure 3.2. Temperature-Dependent Elastic Modulus (Pascals)

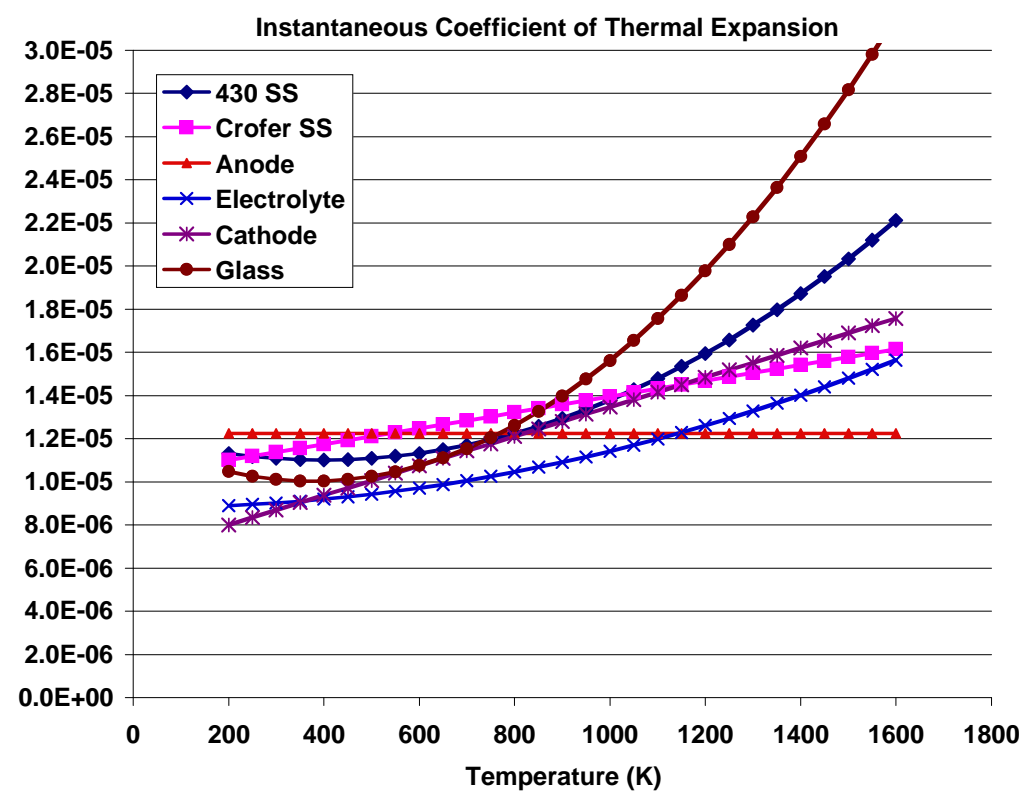

Figure 3.3. Temperature-Dependent Coefficient of Thermal Expansion (1/T) 


\subsection{Results for 10x10-cm Cell Size}

To analyze the effect of \%OCR in the 10x10-cm cell size, model geometries of cross-flow, co-flow, and counter-flow configurations were created as described in Section 3. For each flow configuration, cases simulating OCR ranging from 0 to $80 \%$ per compositions summarized in Table 3.1, and air flow rates associated with air utilizations of $30 \%$ and $15 \%$ were performed. Enough fuel mixtures were simulated to identify the thermal and power output behavior trends for each flow configuration, but not all of the fuel mixtures were simulated for all geometries.

\subsection{Cross Flow $10 \times 10 \mathrm{~cm}$}

Figure 4.1 shows the cell $\Delta \mathrm{T}$ (triangular icons), and the maximum principal stress (S1) in the anode (red square or green " $\mathrm{x}$ " icons) for each $10 \mathrm{x} 10-\mathrm{cm}$ cross-flow case versus \%OCR. The scale for the cell $\Delta \mathrm{T}$ is at left in the figure and that for the stress is at right. Cell $\Delta \mathrm{T}$ for this generic $10 \times 10$ cross-flow stack and $30 \%$ air utilization varied between $74^{\circ}$ and $82^{\circ} \mathrm{C}$ with a minimum at $50 \%$ OCR. The anode stress somewhat followed the trend of $\Delta \mathrm{T}$ and exhibited a minimum value at intermediate \%OCR for $30 \%$ air use. As shown in the figure, when more air was supplied to the stack ( $15 \%$ air use) the variation of stress was decreased, but the magnitude of the stress was not decreased substantially. For both air utilizations, the minimum anode stress was about 14-MPa. These results are summarized in Table 4.1.

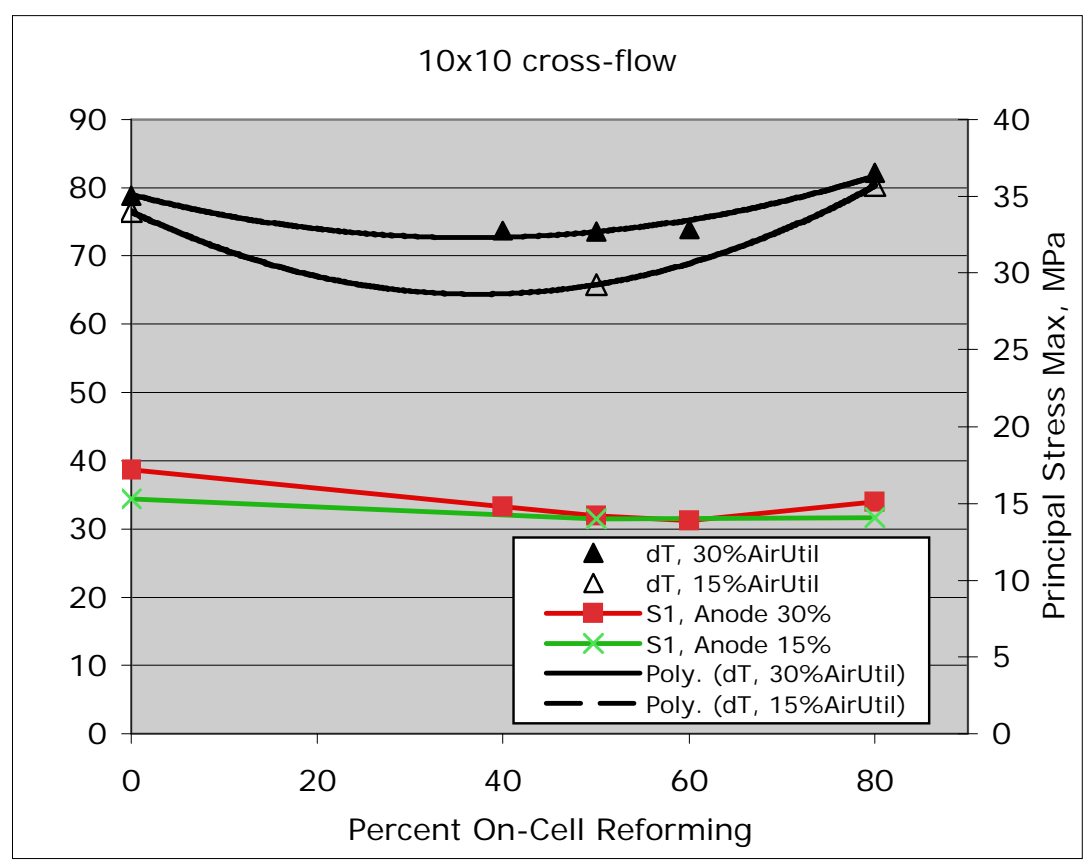

Figure 4.1. Cell Temperature Difference $(\Delta \mathrm{T})$ and Maximum Principal Stress (S1) Versus \%OCR for 10x10-cm Cross-Flow Cases 
Table 4.1. Summary of Results for $10 \times 10-c m$ Cell Size (75/30\% fuel/air utilization). Cases below the dashed line in each block of data are results for $15 \%$ air utilization.

\begin{tabular}{|c|c|c|c|c|c|c|c|c|c|c|c|c|}
\hline \multirow{2}{*}{ Case } & \multirow{2}{*}{$\% O C R$} & \multicolumn{4}{|c|}{ Temperature, ${ }^{\circ} \mathrm{C}$} & \multirow{2}{*}{$\begin{array}{c}\begin{array}{c}\text { Anode } \\
\text { Stress }\end{array} \\
\text { S1 max, } \\
\text { MPa }\end{array}$} & \multirow{2}{*}{$\frac{\text { Power }}{W / \mathbf{c m}^{2}}$} & \multirow{2}{*}{$\begin{array}{c}\text { Heat In } \\
\text { Total }\end{array}$} & \multicolumn{4}{|c|}{ Heat Out, W } \\
\hline & & Inflow & Min & Max & $\Delta \mathrm{T}$ & & & & Air & Fuel & Walls & Total \\
\hline \multicolumn{13}{|c|}{ Cross-Flow Cases: 10x10 } \\
\hline 1 & 0 & 550 & 699 & 778 & 79 & 17.2 & 0.404 & 40.5 & -12.1 & -16.7 & $\mid-11.7$ & -40.5 \\
\hline 2 & 40 & 651 & 700 & 774 & 74 & 14.8 & 0.403 & 30.3 & -3.4 & -15.7 & -11.2 & -30.3 \\
\hline 3 & 50 & 677 & 701 & 775 & 74 & 14.2 & 0.403 & 27.9 & -1.2 & -15.5 & $\mid-11.2$ & -27.9 \\
\hline 4 & 60 & 701 & 701 & 775 & 74 & 13.9 & 0.403 & 25.4 & 0.9 & -15.2 & -11.2 & -25.4 \\
\hline 5 & 80 & 748 & 696 & 778 & 82 & 15.1 & 0.403 & 20.7 & 4.8 & $\begin{array}{l}-14.6 \\
\end{array}$ & -11.0 & -20.7 \\
\hline 6 & 0 & 644 & 703 & 779 & 77 & 15.3 & 0.405 & 40.4 & -14.4 & -14.4 & -11.6 & -40.4 \\
\hline 7 & 50 & 709 & 708 & 774 & 66 & 14.0 & 0.405 & 27.8 & -2.0 & -14.7 & $\mid-11.1$ & -27.8 \\
\hline 8 & 80 & 746 & 697 & 777 & 80 & 14.1 & 0.404 & 20.6 & 4.9 & -14.5 & $\mid-11.0$ & -20.6 \\
\hline \multicolumn{13}{|c|}{ Co-Flow Cases: 10x10 } \\
\hline 9 & 0 & 559 & 699 & 776 & 77 & 18.4 & 0.404 & 40.4 & -11.6 & -17.5 & -11.3 & -40.4 \\
\hline 10 & 40 & 665 & 703 & 777 & 74 & 17.9 & 0.403 & 30.3 & -3.4 & -16.0 & -11.0 & -30.3 \\
\hline 11 & 50 & 691 & 704 & 777 & 73 & 17.7 & 0.403 & 27.9 & -1.3 & -15.6 & -10.9 & -27.9 \\
\hline 12 & 60 & 716 & 705 & 777 & 72 & 17.6 & 0.403 & 25.5 & 0.6 & -15.2 & -10.9 & -25.5 \\
\hline 13 & 80 & 758 & 704 & 779 & 74 & 17.2 & 0.402 & 20.8 & 3.7 & $\begin{array}{l}-14.6 \\
\end{array}$ & -9.8 & -20.8 \\
\hline 14 & 0 & 645 & 707 & 774 & 68 & 16.2 & 0.406 & 40.3 & -13.9 & -15.4 & -11.0 & -40.3 \\
\hline 15 & 50 & 722 & 712 & 775 & 63 & 15.4 & 0.404 & 27.8 & -1.9 & -14.9 & $\mid-11.0$ & -27.8 \\
\hline 16 & 80 & 759 & 711 & 777 & 66 & 14.8 & 0.403 & 20.8 & 3.3 & -14.4 & -9.7 & -20.8 \\
\hline \multicolumn{13}{|c|}{ Counter-Flow Cases: 10x10 } \\
\hline 17 & 0 & 529 & 696 & 781 & 85 & 25.8 & 0.408 & 40.2 & -13.6 & -15.3 & \begin{tabular}{|l|}
-11.3 \\
\end{tabular} & -40.2 \\
\hline 18 & 20 & 572 & 710 & 772 & 62 & 19.9 & 0.406 & 35.2 & -9.0 & -15.3 & -10.8 & -35.2 \\
\hline 19 & 40 & 617 & 723 & 768 & 45 & 13.8 & 0.405 & 30.2 & -4.4 & -15.3 & -10.5 & -30.2 \\
\hline 20 & 50 & 640 & 721 & 768 & 47 & 14.7 & 0.404 & 27.8 & -2.1 & -15.3 & \begin{tabular}{|l|}
-10.4 \\
\end{tabular} & -27.8 \\
\hline 21 & 60 & 663 & \begin{tabular}{|l|}
715 \\
\end{tabular} & \begin{tabular}{|l|}
769 \\
\end{tabular} & 54 & 16.3 & 0.404 & 25.4 & 0.1 & -15.2 & \begin{tabular}{|l|}
-10.3 \\
\end{tabular} & -25.4 \\
\hline 22 & 70 & 685 & 709 & 771 & 62 & 17.8 & 0.404 & 23.0 & 2.4 & -15.1 & \begin{tabular}{|l|}
-10.2 \\
\end{tabular} & -23.0 \\
\hline 23 & 80 & 705 & 704 & \begin{tabular}{|l|}
773 \\
\end{tabular} & 69 & 19.0 & 0.403 & 20.7 & 4.2 & $\begin{array}{l}-15.0 \\
\end{array}$ & -9.9 & -20.7 \\
\hline 24 & 0 & 637 & 700 & 785 & 85 & 22.9 & 0.409 & 40.1 & -16.1 & -12.9 & -11.1 & -40.1 \\
\hline 25 & 50 & 683 & 724 & 768 & 44 & 13.3 & 0.406 & 27.7 & -3.3 & -14.1 & $\mid-10.3$ & -27.6 \\
\hline 26 & 80 & 710 & 712 & 769 & 57 & 14.9 & 0.405 & 20.6 & 3.9 & -14.4 & -10.1 & -20.6 \\
\hline
\end{tabular}

The inflow temperature increased linearly with increasing \%OCR. Table 4.1 provides a summary of results from the 10x10 cross-flow, as well as co-, and counter-flow cases. In the table, for cases 1-5 as indicated in the left-most column, the total stack heat load column labeled "Heat In" shows a linear decrease with increasing \%OCR. The linear inflow temperature increase was coincident with the linear decrease of heat load. As the heat load decreased, the inflow temperature was increased to maintain the average cell temperature. 
The heat flow out of the stack (for cases $1-5$ in Table 4.1) through the perimeter walls and the heat removed by the fuel stream decreased only slightly with increasing \%OCR, while heat removed by the air stream decreased sharply. The direction of heat flow associated with the air became positive (net Heat In) for \%OCR above 50\%; hence, the air had shifted from providing cooling to the stack to providing net heat into the stack. This was also predicted for the $15 \%$ air use cases (cases 6-8). Independent of the air flow rates, temperature differences, and \%OCR, the gross output power density for each case (including cross-, co-, and counter-flow stacks) was virtually constant at $0.40 \mathrm{~W} / \mathrm{cm}^{2}$. Hence the electrical performance was stable for all $10 \times 10-\mathrm{cm}$ stack cases.

\subsection{Co-Flow $10 \times 10 \mathrm{~cm}$}

Figure 4.2 plots the cell $\Delta \mathrm{T}$ and maximum principal stress in the anode for the $10 \mathrm{x} 10-\mathrm{cm}$ coflow stack cases. The figure shows little change to the magnitudes of $\Delta \mathrm{T}$ and the anode stress over the range of \%OCR. However, this $10 \times 10-\mathrm{cm}$ co-flow stack benefited from increased cathode air flow (15\% air use) in the form of decreased $\Delta \mathrm{T}$ and stress over the full range of \%OCR. Stresses in the anode for this co-flow case were similar in magnitude to those predicted for the cross-flow stack.

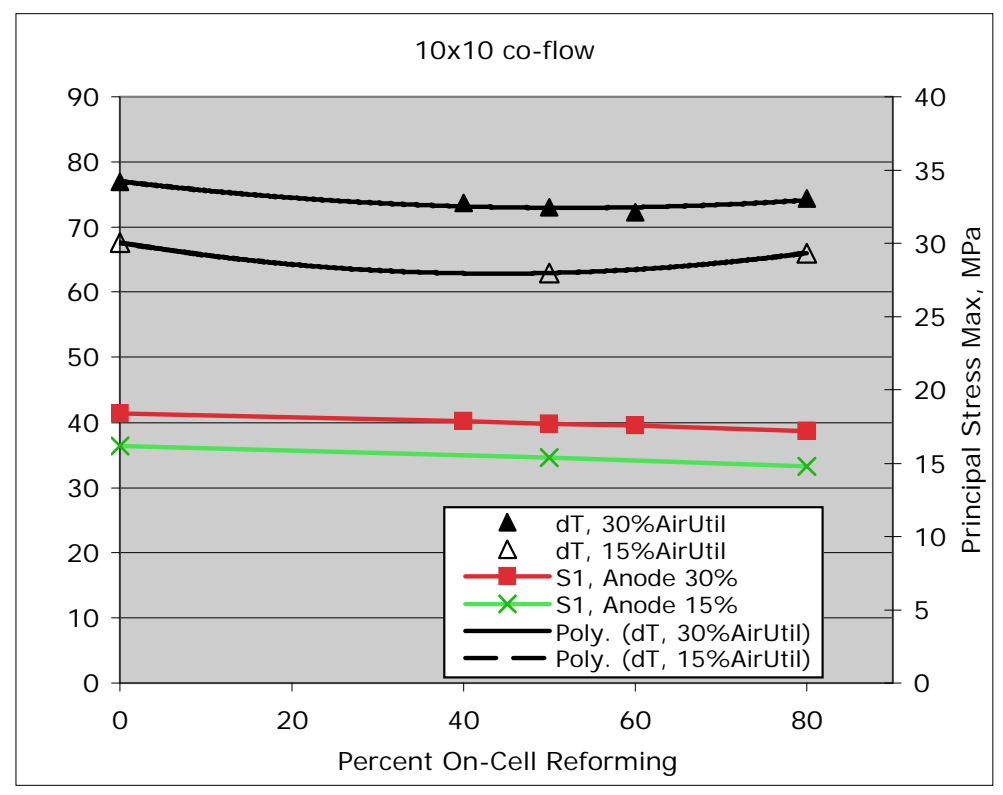

Figure 4.2. Cell Temperature Difference $(\Delta \mathrm{T})$ and Maximum Principal Stress (S1) Versus \%OCR for 10x10-cm Co-Flow Cases 


\subsection{Counter-Flow $10 \times 10 \mathrm{~cm}$}

The 10x10-cm counter-flow cases plotted in Figure 4.3 show a definite thermal benefit for intermediate \%OCR because the models predicted the anode stress to decrease from $25 \mathrm{MPa}$ at $0 \%$ OCR to a minimum of $13.8 \mathrm{MPa}$ at $40 \%$ OCR. The minimum stress was comparable to that predicted for cross-flow and co-flow stacks. Similarly, $\Delta \mathrm{T}$ decreased from $85^{\circ} \mathrm{C}$ at $0 \%$ OCR to $45^{\circ}-47^{\circ} \mathrm{C}$ at $40-50 \%$ OCR. The $45^{\circ}-47^{\circ} \mathrm{C}$ temperature differences were substantially less than those exhibited by either the cross- or co-flow configuration stacks in the 10x10-cm cell size. However, the maximum cell temperature was not substantially lower than the other stacks. The counter-flow stack benefited from $15 \%$ air use because the stresses were less than those of the $30 \%$ air utilization cases. While the benefit of intermediate \%OCR is apparent for the counterflow stack, the results indicate the thermal performance is also more sensitive to the effect of OCR than the cross- and co-flow stacks.

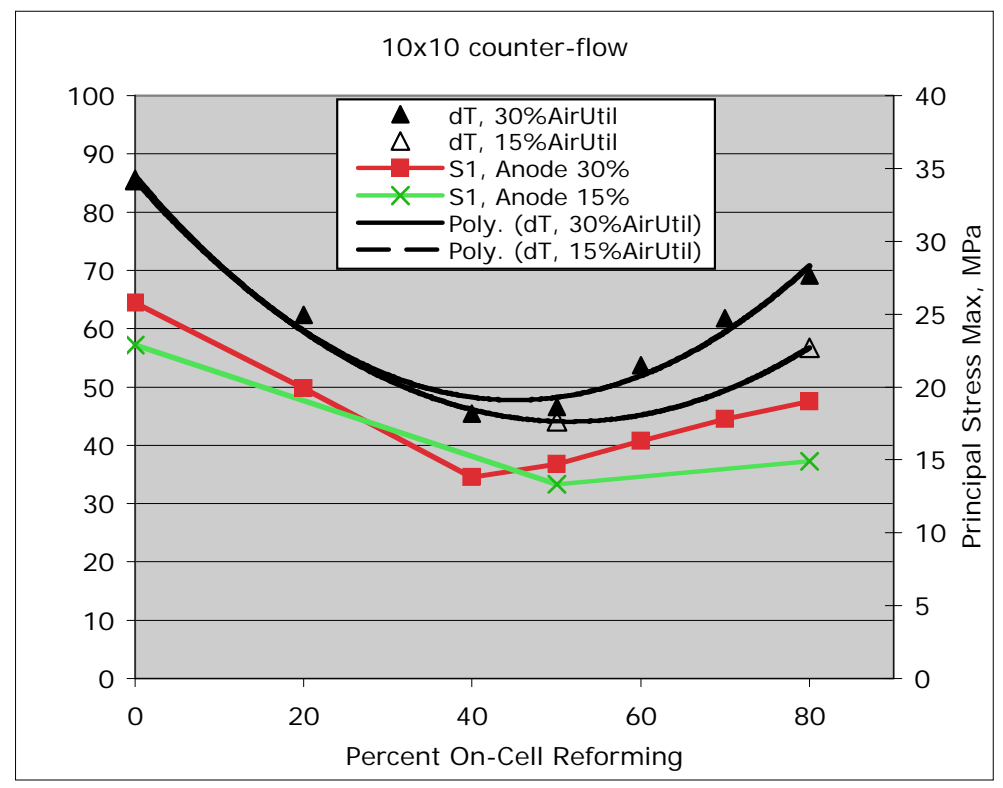

Figure 4.3. Cell Temperature Difference $(\Delta \mathrm{T})$ and Maximum Principal Stress (S1) Versus \%OCR for 10x10-cm Counter-Flow Cases

\subsection{Temperature Distributions and Stress: $10 \times 10 \mathrm{~cm}$}

The distribution of thermally induced stresses in a planar SOFC anode depends on the distribution of temperature. The temperature distribution is affected by the stack flow configuration (geometry), air utilization, and \%OCR. Other variables affecting the temperature that were not addressed by this study include the thermal conductivity, thickness of stack components, fuel utilization, and stack wall boundary conditions, to name a few. Even without the effect of these other variables, the temperature distribution was unique for each simulation case. As was demonstrated above, the temperature and anode stress were particularly sensitive to \%OCR in 
the $10 \times 10$-cm counter-flow stack. This result, due to changes in the temperature distribution, is illustrated in Figure 4.4, which shows distributions of anode temperature and stress for cases 17, 19, and 23 from Table 4.1. In the orientation shown in the figure, air flowed across the cell from the left, and fuel flowed from the right. With $0 \%$ OCR, the distribution of temperature (a) indicated that the primary cooling came from the air (at left). Subsequently, the maximum temperature and maximum stress (b) occurred near the air outflow (at right). With $40 \%$ OCR, cooling was provided by the air and by the reformation of methane (at right). In this case the distributions of temperature (c) and stress (d) were more centrally located on the anode. With $80 \%$ OCR, less cooling was provided by the air, and a larger portion was provided by the reformation of methane. Hence maximums in temperature (e) and stress (f) occurred nearer the air inflow edge of the cell (at left). This suggests that the symmetric temperature profile with the maximum at the center is the most beneficial regarding anode stresses.

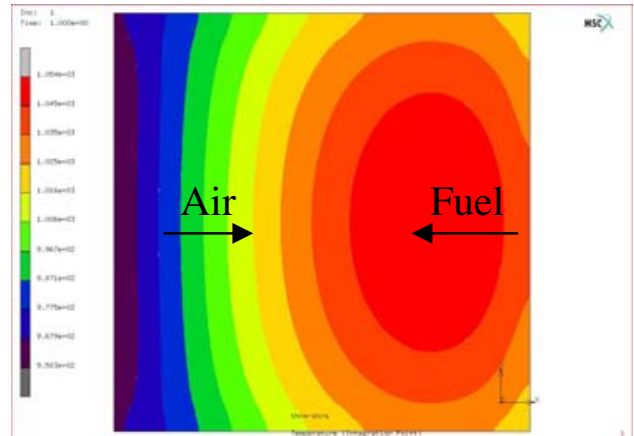

a)

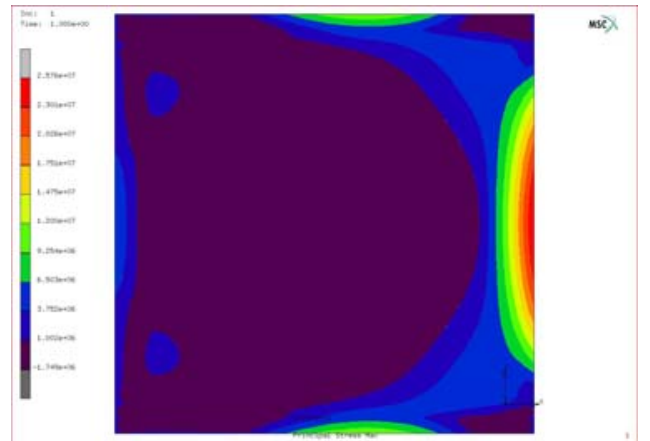

b)

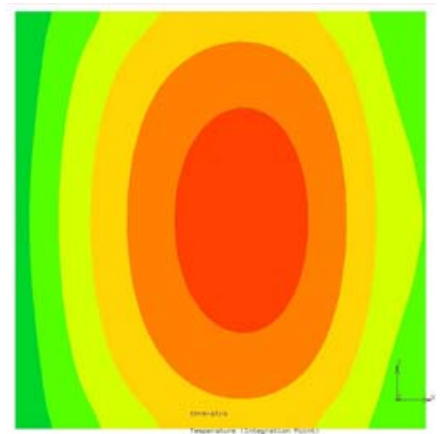

c)

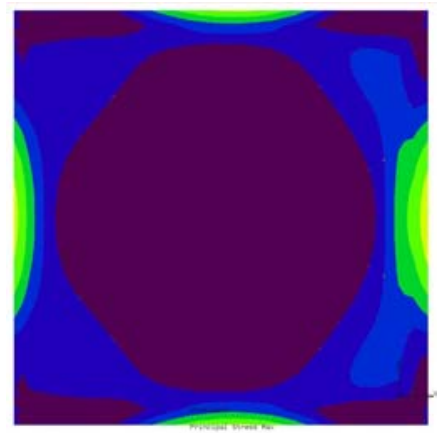

d)

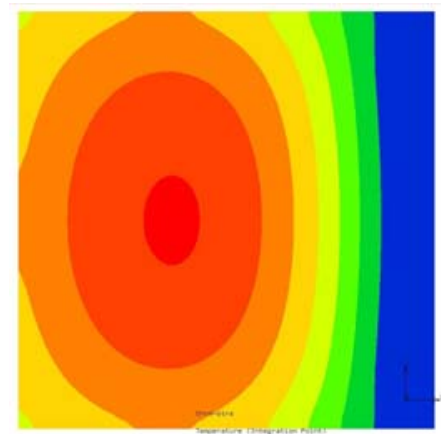

e)

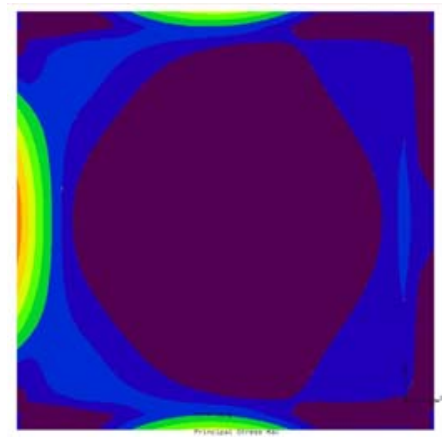

f)

Figure 4.4. Distributions of Anode Temperature (top) and Maximum Principal Stress (bottom) within a 10x10-cm Counter-Flow Stack Operating with (a,b) $0 \%$ OCR, (c,d) $40 \%$ OCR, and (e,f) $80 \%$ OCR. Temperature color scale is $958 \mathrm{~K}$ to $1054 \mathrm{~K}\left(685^{\circ}-781^{\circ} \mathrm{C}\right)$. Stress color scale is -1.75 to $25.8 \mathrm{MPa}$. 


\subsection{Results: 20x20-cm Cell Size}

To analyze the effect of \%OCR in the 20x20-cm cell size, model geometries of cross-flow, co-flow, and counter-flow were created. For each flow configuration, cases simulating OCR ranging from 0 to $80 \%$ and air flow rates associated with air utilizations of 30 and $15 \%$ were performed. A sufficient number of fuel mixtures were simulated to identify the behavior trends of each flow configuration; thus, not all of the fuel mixtures were simulated for all geometries.

\subsection{Cross-Flow 20x20 cm}

Figure 5.1 plots cell $\Delta \mathrm{T}$ and maximum principal stress in the anode for the 20x20-cm crossflow cases. Legends and labeling are consistent with the figures in Section 4. Cell temperature differences for this generic cross-flow stack with $15 \%$ air utilization were very large, varying in magnitude from $236^{\circ}$ to $310^{\circ} \mathrm{C}$ with a minimum $\Delta \mathrm{T}$ in the 40 to $50 \%$ OCR range. The anode stress was also quite large with $30 \%$ air utilization (red squares in Figure 5.1) and featured a minimum value of $60.2-\mathrm{MPa}$ at $50 \%$ OCR. The stresses decreased substantially and were less varied with $15 \%$ air use, indicating that increased air flow represents an improvement in the operating conditions for this $20 \times 20$-cm stack.

Table 5.1 summarizes the simulation results from the 20x20-cm cross-flow, co-flow, and counter-flow cases. As with the smaller cell size, the inflow temperature increased linearly with increasing \%OCR. As the heat load decreased, the inflow temperature increased to maintain the

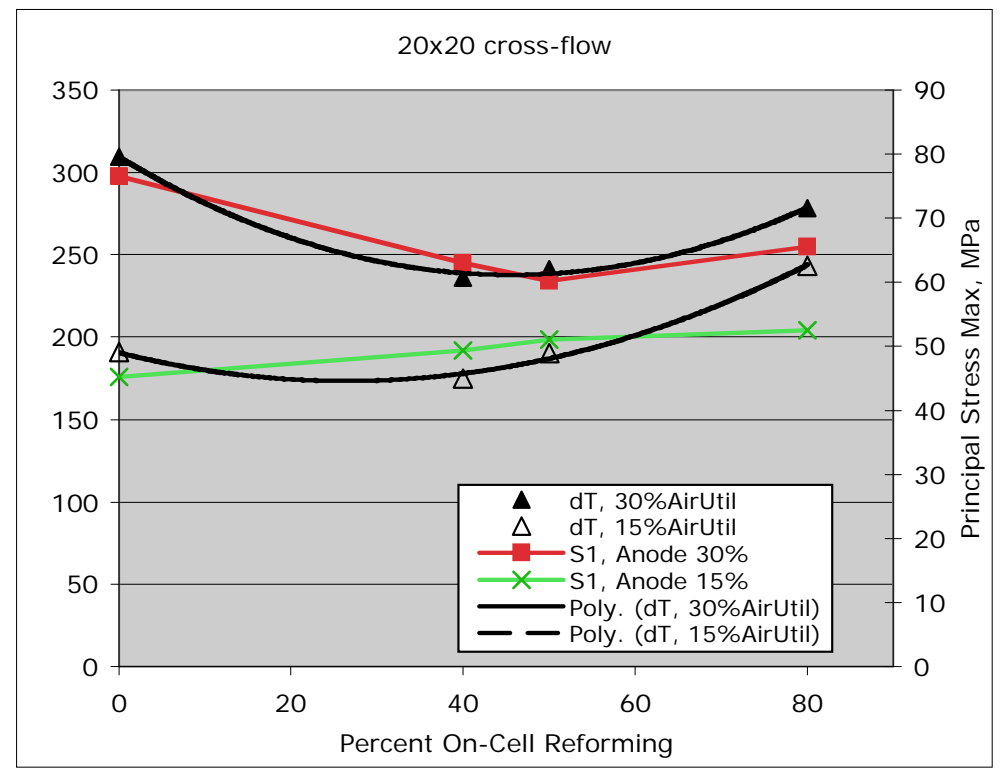

Figure 5.1. $\quad$ Cell Temperature Difference $(\Delta \mathrm{T})$ and Maximum Principal Stress (S1) Versus \%OCR for 20x20-cm Cross-Flow Cases 
Table 5.1. Summary of Results for $20 \times 20-\mathrm{cm}$ Cell Size (75/30\% fuel/air utilization). Cases below the dashed line in each block of data are results for $15 \%$ air utilization.

\begin{tabular}{|c|c|c|c|c|c|c|c|c|c|c|c|c|}
\hline \multirow{2}{*}{ Case } & \multirow{2}{*}{$\% O C R$} & \multicolumn{4}{|c|}{ Temperature, ${ }^{\circ} \mathbf{C}$} & \multirow{2}{*}{$\begin{array}{c}\text { Anode } \\
\text { Stress } \\
\text { S1max, } \\
\text { MPa }\end{array}$} & \multirow{2}{*}{$\frac{\text { Power }}{W / \mathbf{c m}^{2}}$} & \multirow{2}{*}{$\frac{\text { Heat In }}{\text { Total }}$} & \multicolumn{4}{|c|}{ Heat Out, W } \\
\hline & & Inflow & Min & Max & $\Delta \mathbf{T}$ & & & & Air & Fuel & Walls & Total \\
\hline \multicolumn{13}{|c|}{ Cross-Flow Cases: 20x20 } \\
\hline 27 & 0 & 489 & 588 & 897 & 310 & 76.5 & 0.372 & 175.8 & $\begin{array}{l}-87.6 \\
\end{array}$ & -68.0 & -20.2 & -175.8 \\
\hline 28 & 40 & 612 & 624 & 859 & 236 & 63.0 & 0.395 & 125.2 & -35.8 & -70.5 & -18.9 & -125.2 \\
\hline 29 & 50 & 641 & 624 & 866 & 241 & 60.2 & 0.399 & 113.3 & -22.6 & \begin{tabular}{|c|}
-70.8 \\
\end{tabular} & -19.9 & -113.3 \\
\hline 30 & 80 & 718 & 600 & 878 & 278 & 65.5 & 0.406 & 81.2 & 11.5 & \begin{tabular}{|c|}
-70.3 \\
\end{tabular} & -22.3 & -81.2 \\
\hline 31 & 0 & 638 & 660 & 851 & 191 & 45.2 & 0.397 & 165.2 & -87.4 & -55.7 & -22.0 & -165.2 \\
\hline 32 & 40 & 679 & 663 & 837 & 175 & 49.3 & 0.401 & 122.7 & -41.5 & $\begin{array}{l}-61.6 \\
\end{array}$ & -19.6 & -122.7 \\
\hline 33 & 50 & 690 & 653 & 844 & 190 & 51.0 & 0.402 & 112.1 & -29.6 & $\begin{array}{ll}-62.8 \\
\end{array}$ & \begin{tabular}{|l|}
-19.7 \\
\end{tabular} & -112.1 \\
\hline 34 & 80 & 727 & 613 & \begin{tabular}{|l|}
857 \\
\end{tabular} & 243 & 52.5 & 0.407 & 81.3 & 4.2 & -65.1 & -20.4 & -81.3 \\
\hline \multicolumn{13}{|c|}{ Co-Flow Cases: 20x20 } \\
\hline 35 & 0 & 571 & 628 & 847 & 220 & 46.9 & 0.407 & 160.2 & -60.6 & -78.1 & -21.5 & -160.2 \\
\hline 36 & 50 & 701 & 659 & 846 & 187 & 42.7 & 0.404 & 110.6 & -18.6 & $\begin{array}{ll}-69.8 \\
\end{array}$ & -22.3 & -87.3 \\
\hline 37 & 80 & 778 & 665 & 844 & 178 & 40.0 & 0.403 & 82.5 & 4.7 & -64.9 & -22.2 & -82.5 \\
\hline 38 & 0 & 648 & 671 & 819 & 148 & 29.8 & 0.407 & 160.5 & -73.2 & -66.5 & -20.8 & -160.5 \\
\hline 39 & 50 & 724 & 690 & 817 & 127 & 27.0 & 0.405 & 110.6 & -24.7 & $\begin{array}{ll}-64.2 \\
\end{array}$ & -21.7 & $\overline{-110.6}$ \\
\hline 40 & 80 & 766 & 693 & 817 & 124 & 25.5 & 0.404 & 82.3 & 1.4 & $\begin{array}{ll}-61.8 \\
\end{array}$ & -21.9 & -82.3 \\
\hline \multicolumn{13}{|c|}{ Counter-Flow Cases: 20x20 } \\
\hline 41 & 0 & 478 & 578 & 882 & 304 & 87.6 & 0.419 & 156.2 & -87.2 & -48.8 & -20.3 & -156.2 \\
\hline 42 & 40 & 509 & 612 & 841 & 228 & 79.1 & 0.412 & 118.3 & -50.9 & -53.0 & -14.4 & -118.3 \\
\hline 43 & 50 & 519 & 623 & 835 & 212 & 74.1 & 0.411 & 109.0 & -41.5 & -54.3 & -13.2 & -109.0 \\
\hline 44 & 60 & 530 & 635 & 832 & 196 & 71.7 & 0.409 & 99.8 & -32.0 & -55.5 & -12.3 & -99.8 \\
\hline 45 & 80 & 564 & 651 & 829 & 178 & 78.8 & 0.408 & 81.4 & -11.7 & -58.5 & -11.3 & -81.5 \\
\hline 46 & 0 & 645 & 663 & 851 & 188 & 45.4 & 0.415 & 158.0 & -90.1 & -46.2 & -21.8 & -158.0 \\
\hline 47 & 50 & 649 & 670 & 821 & 150 & 55.2 & 0.411 & 108.9 & -41.5 & -50.4 & -16.9 & $\begin{array}{c}-108.8 \\
\end{array}$ \\
\hline 48 & 80 & 656 & 679 & 816 & 137 & 56.5 & 0.409 & 80.9 & -14.1 & -52.2 & -14.6 & -80.9 \\
\hline
\end{tabular}

average cell temperature at $750^{\circ} \mathrm{C}$. Also, the heat flow from the stack through the perimeter walls and the heat removed by the fuel stream were roughly constant, while heat removed by the air stream decreased sharply with increasing \%OCR. As in the smaller cell size cases, the heat removed by the air became positive (net heat in) for OCR above 50\%; hence, the air had shifted from cooling the stack to heating the stack.

\subsection{Co-Flow $20 \times 20 \mathrm{~cm}$}

Figure 5.2 plots cell $\Delta \mathrm{T}$ and maximum principal stress in the anode for the 20x20-cm co-flow cases. Over the range of \%OCR, the magnitude of the anode stress decreased without a minimum from $46.9 \mathrm{MPa}$ at $0 \%$ to $40.0 \mathrm{MPa}$ at $80 \%$ OCR for $30 \%$ air use. The results also show a performance benefit from operating the stack at 15\% air utilization (cases 38-40 in Table 5.1) 


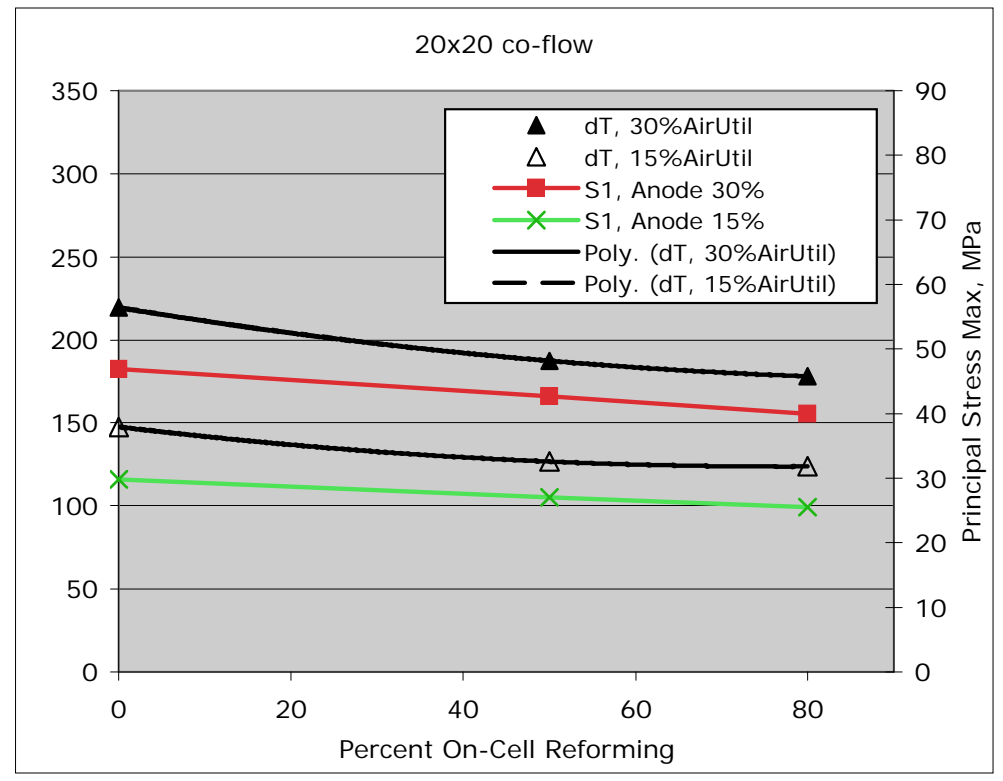

Figure 5.2. Cell Temperature Difference $(\Delta \mathrm{T})$ and Maximum Principal Stress (S1) Versus \%OCR for 20x20-cm Co-Flow Cases

as the anode stresses were further decreased to 25.5-MPa at $80 \% \mathrm{OCR}$. These anode stresses were considerably lower than those of the cross-flow stack. Likewise, the cell $\Delta \mathrm{T}$ was decreased to $148^{\circ} \mathrm{C}$ at $0 \%$ and $124^{\circ} \mathrm{C}$ at $80 \%$ OCR, decreasing continuously with increasing \%OCR.

\subsection{Counter-Flow $20 \times 20 \mathrm{~cm}$}

The 20x20-cm counter-flow stack was predicted to have the largest anode stresses of the three 20x20-cm stack geometries examined. Figure 5.3 plots the cell $\Delta \mathrm{T}$ and maximum principal stress in the anode for this stack. Anode stress ranged from 87.6 MPa at 0\% OCR to 71.7 $\mathrm{MPa}$ at $60 \%$ OCR at $30 \%$ air utilization. Figure 5.4 shows distributions of the anode temperature and stress for 0,60 , and $80 \%$ OCR and 30\% air use (cases 41, 44, and 45 from Table 5.1). The distributions of temperature and stress were very similar to those of the 10x10-cm counter-flow cases (Figure 4.4). Anode stress was lowest for an intermediate (60\%) OCR case. This case had a symmetric temperature profile with the maximum at the center. However, the stress increased while the cell $\Delta \mathrm{T}$ continued to decrease as the OCR approached $80 \%$. While the $80 \%$ OCR case also had a symmetric temperature profile with the maximum at the center, the elevated anode stress may be attributable to the more closely spaced isotherms (or larger thermal gradients) in the anode (Figure 5.4e) compared to the 60\% OCR case (Figure 5.4c).

Stresses were less but still large with 15\% air use, ranging from a minimum of $45.4 \mathrm{MPa}$ at $0 \%$ to a maximum of $56.5 \mathrm{MPa}$ at $80 \%$ OCR. The predicted cell temperature difference was quite large $\left(304^{\circ} \mathrm{C}\right)$ at $0 \%$ OCR and $30 \%$ air utilization and consistently decreased with 


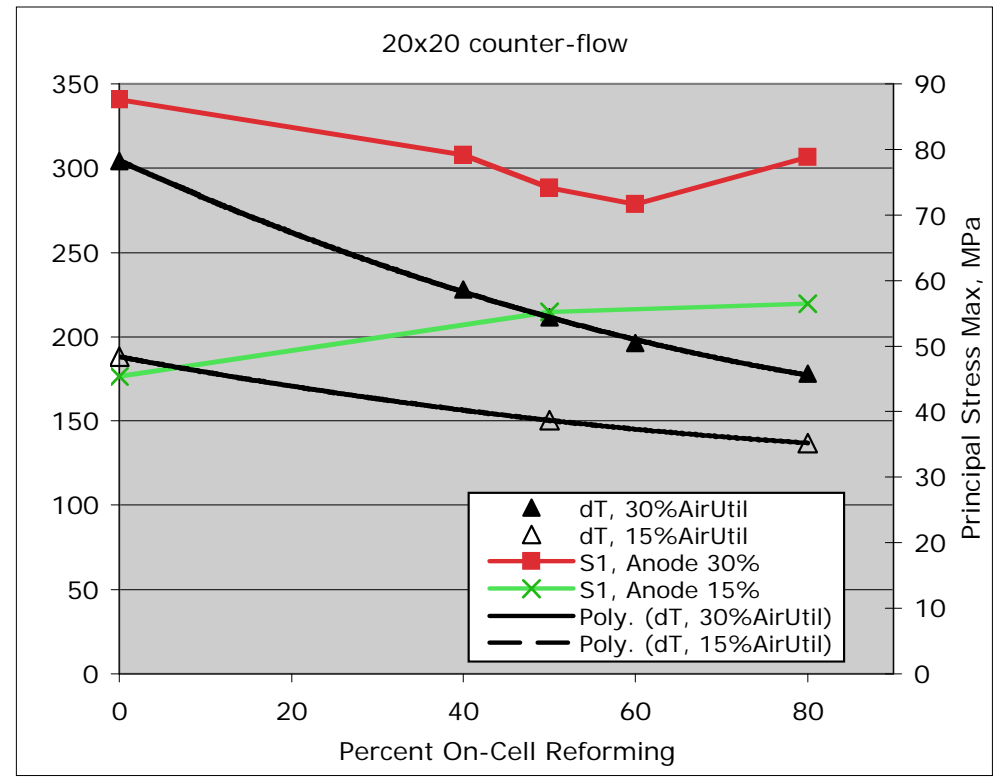

Figure 5.3. Cell Temperature Difference $(\Delta \mathrm{T})$ and Maximum Principal Stress (S1) Versus \%OCR for 20x20-cm Counter-Flow Cases

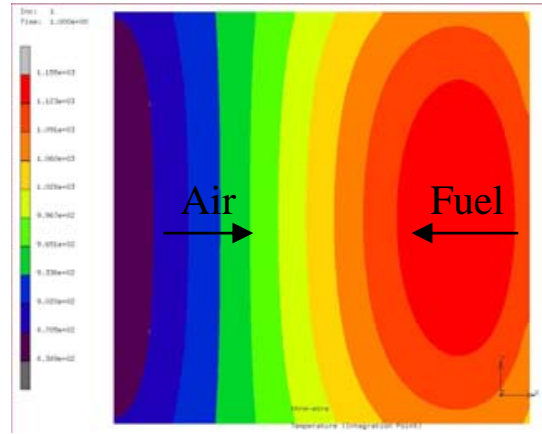

a)

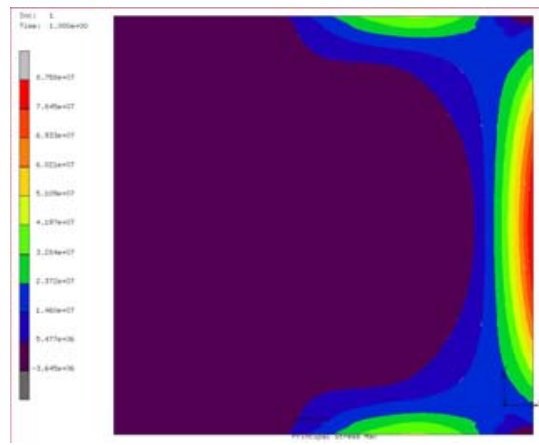

b)

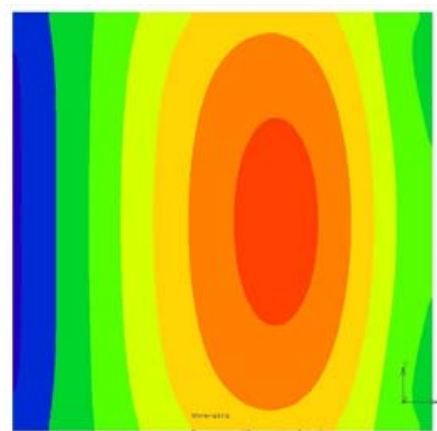

c)

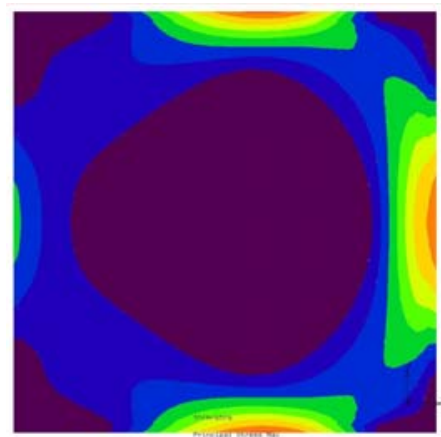

d)

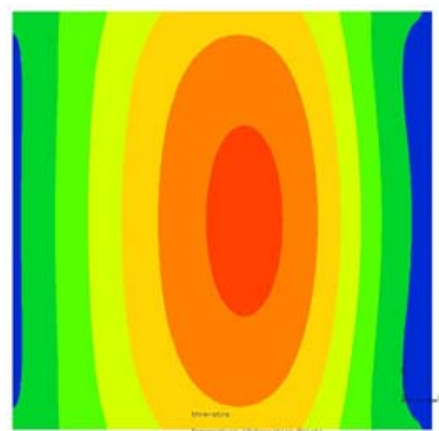

e)

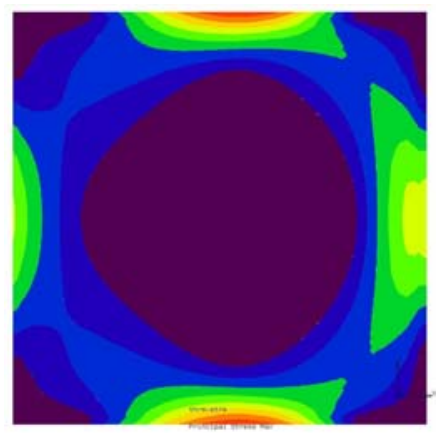

f)

Figure 5.4. Distributions of Anode Temperature (top) and Maximum Principal Stress (bottom) within a 20x20-cm Counter-Flow Stack Operating with (a,b) 0\% OCR, (c,d) 60\% OCR, and (e,f) $80 \%$ OCR. Temperature color scale is 839 to $1155 \mathrm{~K}\left(566^{\circ}-882^{\circ} \mathrm{C}\right)$. Stress color scale is -3.65 to $87.6 \mathrm{MPa}$. 
increasing \%OCR and increased air flow (15\% air utilization). The counter-flow stack did not perform as well as the co-flow stack.

In both the co-flow and counter-flow configurations, $\Delta \mathrm{T}$ was predicted to decrease without minimum with increasing \%OCR and $15 \%$ air utilization (double air flow). However, the magnitude of the cell $\Delta \mathrm{T}$ was consistently and considerably smaller in the co-flow stack (see cases 35-40 in Table 5.1). More importantly, it was shown that the anode stresses resulting from the temperature distributions were substantially smaller in the co-flow stack.

\subsection{Power Density $20 \times 20 \mathrm{~cm}$}

Power density was nearly invariant within the $10 \times 10$-cm cases independent of \%OCR and flow configuration. However, within the 20x20-cm cases, cross-flow with $0 \%$ OCR and $30 \%$ air utilization (Case 27, Table 5.1) had conspicuously low power density (7\% low relative to similar co- and counter-flow cases) and a very large temperature difference $\left(310^{\circ} \mathrm{C}\right)$. Increased air flow and 15\% air utilization (Case 31, Table 5.1) enabled a large increase in the inflow temperature, which helped to substantially decrease the cell $\Delta \mathrm{T}$ and boost the Nernst potential. The average Nernst potential (and power listed in Table 5.1) increased to within $2 \%$ of the average of all 20x20-cm cases.

\subsection{Cathode Air Utilization}

In this study, the nominal pressure drop for one of the $20 x 20-\mathrm{cm}$ cells with $30 \%$ air utilization, with 1-mm-tall by 1-mm-wide channels, spaced by 1-mm-wide fins on the interconnect, would be approximately 0.34 psi. Cases in which the cathode air flow rate was doubled (15\% air utilization) would have increased cathode channel pressure drop proportional to $0.68 \mathrm{psi}$ if the cathode channel height was left unaltered. Assuming a pumping efficiency of 0.5 for a 100-cell stack, this would increase the power required to pump air through the cathode by a factor of 4. Similarly low efficiencies are often suffered when relatively low flow rates and high head losses are required. Higher efficiencies could be possible if larger high-speed pumps were used to provide air for multiple stacks. ${ }^{11}$ The benefit that increased air flow can provide in the form of decreased thermal stress must be balanced with the increased cathode pressure drop and blower power requirement. However, the 20x20-cm cell stacks examined in this study required increased air flow (15\% air utilization) to achieve reasonably low stresses and anode temperatures. 


\subsection{Conclusions}

The following observations were drawn from the results of this study:

- The analysis showed that the anode stress was a minimum along with the temperature difference on the cell when 40 to $50 \%$ of the reformation reaction took place on-cell in counter-flow and cross-flow stacks of 10x10-cm size.

- Gross electrical power density of $0.40 \mathrm{~W} / \mathrm{cm}^{2}$ was virtually unaffected for each $10 \times 10-\mathrm{cm}$ case. Each of the 20x20-cm cases that exhibited reasonable thermal performance also had power densities that varied from the average of $0.40 \mathrm{~W} / \mathrm{cm}^{2}$ by at most $-1 \%$ to $+2 \%$.

- Inflow gas temperature increased linearly with linearly increasing \%OCR to offset the decreasing heat load and maintain the average cell temperature at $750^{\circ} \mathrm{C}$. Examination of the heat load data showed that the air had shifted roles from providing stack cooling to providing net stack heat for OCR above 50\%. An exception to this was the 20x20-cm counter-flow stack in which the air continued to provide net cooling over the full range of OCR.

- The co-flow stack showed substantial thermal benefit due to increased air flow (and 15\% air utilization) as the anode stress and cell temperature difference was decreased over the full range of OCR. Cross-flow and counter-flow stacks did not show the same consistent benefit.

- Within the 20x20-cm cases the co-flow configuration stack had the smallest anode stresses and cell temperature difference both of which had no minimum, but rather were continuously decreased with increasing OCR.

- For the conditions and particular generic stacks of this study, the results suggest 40 to $50 \%$ reformation on-cell should be considered for cross-flow and counter-flow stacks, and higher percentages may be desirable in co-flow stacks.

- Air utilization of $15 \%$ provided a consistent thermal benefit in the form of decreased anode stress, cell $\Delta \mathrm{T}$, and maximum temperature compared with $30 \%$ air utilization. Although doubling the air flow can result in a factor of 4 increase in the air blower power requirement, a maximum of $15 \%$ air utilization may be necessary in 20x20-cm cell stacks to achieve acceptably low stresses and anode temperatures. 


\subsection{References}

1. Recknagle KP, DT Jarboe, DL King, MA Khaleel, and P Singh. 2005. Modeling of On-Cell Reformation in SOFC Stacks: The Effect of Methane Conversion Activity Manipulations on Stack Performance. PNNL-15311, Pacific Northwest National Laboratory, Richland, Washington.

2. Khaleel MA. 2005. "Finite Element SOFC Analysis with SOFC-MP and MSC.Marc/MentatFC.” Proceedings of the Sixth Annual SECA Workshop. National Engineering Technology Laboratory, Morgantown, West Virginia. Available at http://www.netl.doe.gov/publications/proceedings/05/SECA_Workshop/SECAWorkshop05.html

3. Khaleel MA, Z Lin, P Singh, W Surdoval, and D Collins. 2004. “A Finite Element Analysis Modeling Tool for Solid Oxide Fuel Cell Development: Coupled Electrochemistry, Thermal, and Flow Analysis in Marc.” J. Power Sources, 130(1-2):136-148.

4. Recknagle KP, RE Williford, LA Chick, DR Rector, and MA Khaleel. 2003. “Threedimensional thermo-fluid electrochemical modeling of planar SOFC stacks.” $J$. Power Sources, 113:109-114.

5. Chick LA, JW Stevenson, KD Meinhardt, SP Simner, JE Jaffe, and RE Williford. 2000. "Modeling and Performance of Anode-Supported SOFC." 2000 Fuel Cell Seminar Abstracts, pp. 619-622.

6. Chick LA, RE Williford, JW Stevenson, CF Windisch Jr, and SP Simner. 2002. "Experimentally-Calibrated, Spreadsheet-Based SOFC Unit-Cell Performance Model.” 2002 Fuel Cell Seminar - Abstracts.

7. Keegan K, M Khaleel, L Chick, K Recknagle, S Simner, and J Deibler. 2002. “Analysis of a Planar Solid Oxide Fuel Cell-Based Automotive Auxiliary Power Unit.” Society of Automotive Engineers, Congress 2002 Proceedings, 2002-01-0413.

8. Williford RE, LA Chick, GD Maupin, SP Simner, and JW Stevenson. 2003. “Diffusion Limitations in the Porous Anodes of SOFCs.” J. Electrochemical Soc. 150(8):A1067-A1072.

9. Recknagle KP, P Singh, LA Chick, and MA Khaleel. 2004. "Modeling of SOFC Stacks with On-Cell Steam-Methane Reformation at PNNL.” PNNL-SA-43248, Proceedings of the Fuel Cell 2004 Seminar, San Antonio, Texas.

10. King DL, Y Wang, Y Chin, Y Lin, H Roh, and R Romiarek. 2005. “Controlling Activity and Stability of Ni-YSZ Catalysts for On-Anode Reforming.” Presented at SECA Core Technology Program Review Meeting, Tampa, Florida.

11. Clark T and M Arner. 2002. "Motor Blower Technologies for Fuel Cell Automotive Power Systems.” Hydrogen, Fuel Cells, and Infrastructure Technologies Program Annual Report 2002. U.S. Department of Energy, Washington, D.C., pp. 503-507. Available at http://www.eere.energy.gov/hydrogenandfuelcells/pdfs/33098_toc.pdf. 


\section{Appendix A}

\section{Molar Compositions of Partially Reformed Fuel Mixtures}




\section{Appendix A}

\section{Molar Compositions of Partially Reformed Fuel Mixtures}

Table A.1. Mass Compositions of Partially Reformed Fuel Mixtures Supplied from an External Reformer to the Stack (mass fraction)

\begin{tabular}{|l|c|c|c|c|c|c|c|c|c|}
\hline $\mathbf{O C R}$ & $\mathbf{0 \%}$ & $\mathbf{1 0 \%}$ & $\mathbf{2 0 \%}$ & $\mathbf{3 0 \%}$ & $\mathbf{4 0 \%}$ & $\mathbf{5 0 \%}$ & $\mathbf{6 0 \%}$ & $\mathbf{7 0 \%}$ & $\mathbf{8 0 \%}$ \\
\hline $\mathbf{H}_{\mathbf{2}}$ & 0.08298 & 0.07487 & 0.06664 & 0.05828 & 0.04975 & 0.04101 & 0.03201 & 0.02269 & 0.01295 \\
\hline $\mathbf{H}_{\mathbf{2}} \mathbf{O}$ & 0.24993 & 0.27283 & 0.29676 & 0.32193 & 0.34861 & 0.37713 & 0.40796 & 0.44169 & 0.47913 \\
\hline $\mathbf{C O}$ & 0.27298 & 0.23151 & 0.19164 & 0.15369 & 0.11809 & 0.08536 & 0.05621 & 0.03158 & 0.01272 \\
\hline $\mathbf{C O}_{\mathbf{2}}$ & 0.17663 & 0.18123 & 0.18332 & 0.18238 & 0.17777 & 0.16864 & 0.15389 & 0.13204 & 0.10111 \\
\hline $\mathbf{N}_{\mathbf{2}}$ & 0.21749 & 0.21749 & 0.21749 & 0.21749 & 0.21749 & 0.21749 & 0.21749 & 0.21749 & 0.21749 \\
\hline $\mathbf{C H}_{\mathbf{4}}$ & 0.00000 & 0.02207 & 0.04415 & 0.06622 & 0.08829 & 0.11037 & 0.13244 & 0.15451 & 0.17659 \\
\hline
\end{tabular}

